\title{
Supporting Information for: Tracing the consumption origins of wastewater and sludge for a Chinese city based on waste input-output analysis
}

Lishan XIAO ${ }^{1}$, Chen LIN $^{2 *}$, Shinichiro NAKAMURA ${ }^{3}$

1 School of Environmental and Geographical Sciences, Shanghai Normal University, Shanghai, 200234, China

2 School of Applied Economics, Renmin University of China, Beijing, 100872, China

3 Faculty of Political Science and Economics, Waseda University, Tokyo 169-8050, Japan

Corresponding author, Email: c_lin@ruc.edu.cn

Number of pages: 22, Number of tables: 9 , Number of figures: 2 


\section{Contents}

1 Current state of wastewater and sludge treatment in China sludge growth, laws, and policies in China .........................................................S4

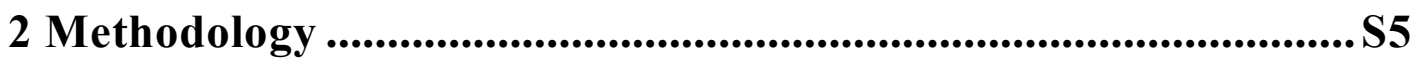

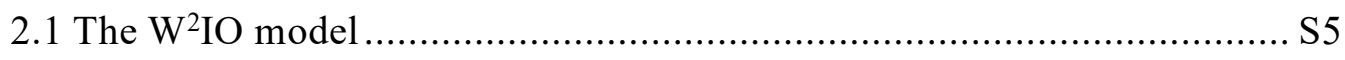

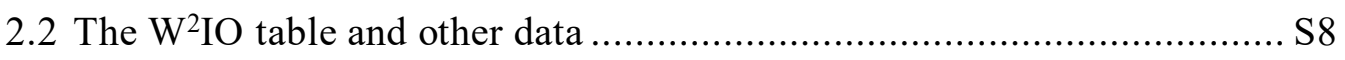

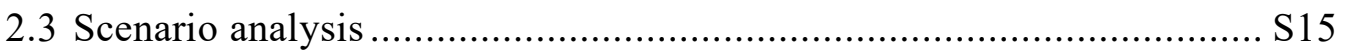

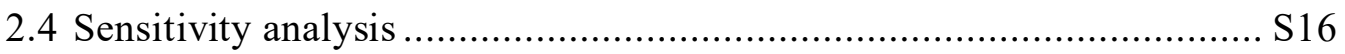

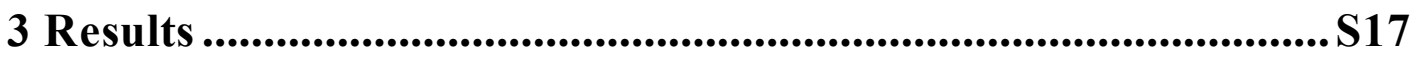

3.1 Wastewater and sludge footprint by final demand categories .............. S17

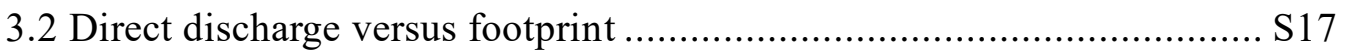

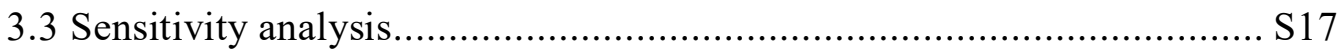

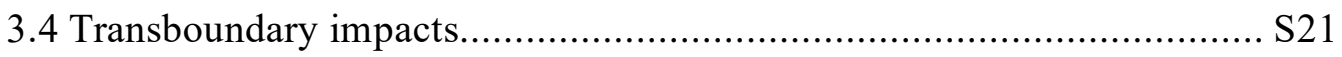

References........................................................................S21

\section{List of Figures}

Figure S1 Wastewater and sludge footprint by final demand categories...............S17

Figure S2 Direct discharge versus $\mathrm{W}^{2} \mathrm{~F}$ of the largest 40 sectors.........................S17

\section{List of Tables}

Table S1 Framework of the $\mathrm{W}^{2} \mathrm{IO}$ table. .S6 
Table S2 Production sector classification: Xiamen IO table. S8

Table S3 The allocation matrix S of waste/wastewater to treatment processes....S12

Table S4 The $\mathrm{W}^{2} \mathrm{IO}$ table of Xiamen based on the framework in Table 1 S13

Table S5 COD and wastewater discharge. S14

Table S6 Data on food (diet, toilet discharge, and carbon content) $\mathrm{S} 15$

Table S7 Sensitivity elasticity of pre-consumption $\mathrm{W}^{2} \mathrm{~F}$ and $\mathrm{SF}$ to input and waste generation coefficients $\mathrm{S} 18$

Table S8 Sensitivity elasticity of post-consumption $\mathrm{W}^{2} \mathrm{~F}$ and SF with respect to key parameters. S20

Table S9 Wastewater and sludge embodied in trade S21 


\section{The current state of wastewater and sludge treatment in}

\section{China}

China has the second-highest wastewater treatment capacity in the world ${ }^{1}$, with 5222 wastewater treatment plants to treat $2.28 \times 10^{8} \mathrm{~m}^{3}$ wastewater every day in 2018 . The sludge in China was 11.7 million tons in 2018, with an average annual growth rate of $10 \%$ from 2011-2018. Sludge is treated by landfilling (50\%), incineration (10\%), materials recycling $(9 \%)$, and composting $(16 \%)^{1}$. Although landfills accounted for the largest part of sludge treatment, it is not a favorable solution in the future. The water content of the sludge for landfills should be less than $60 \%$ after $2007^{2}$. As a result, a large amount of landfilled sludge cannot meet the new requirements and thus is disposed of improperly ${ }^{3}$. Given that $80 \%$ of landfills cannot meet the national standard, only about $45 \%$ of the sludge is properly treated at present.

Sludge for land use and incineration have been recommended as the best available technologies ${ }^{4}$. Sludge treatment should be compatible with technology, economic development level, and environmental management requirement for different application conditions. Furthermore, the zero-waste city plan further proposed to minimize the amount of landfills and ultimately realize the full utilization of waste ${ }^{5}$. In 2020, The latest revision of the Solid Waste Prevention and Control Law confirmed that sludge treatment facilities should be incorporated into the urban wastewater treatment plan. China is in a transition period with respect to wastewater and sludge management from end-pipe disposal to waste-to-resource management. 


\section{Methodology}

\subsection{The $W^{2} I O$ model}

\subsubsection{Derivation of equation}

A hybrid IO model was produced to examine both the generation and treatment of wastewater, as an extension of the WIO in Nakamura and Kondo (2009) ${ }^{6}$. The framework of $\mathrm{W}^{2} \mathrm{IO}$ is presented in Table $\mathrm{S} 1$. Let there be $n$ producing sectors, $k$ waste/wastewater treatment sectors, and $\mathrm{m}$ types of waste/wastewater. The $n \times n$ matrix, $\mathrm{X}_{\mathrm{P}}$, refers to the intermediate input flows in the economic (goods and services producing) sectors, the $n \times k$ matrix $\mathrm{X}_{\mathrm{T}}$ to the input from the economic sectors to the treatment sectors, the $n \times f$ matrix $\mathrm{Y}_{\mathrm{P}}$ to the final demand for goods and services, the $k \times f$ matrix $\mathrm{Y}_{\mathrm{w}}$ to the final demand for wastewater, sludge and ash, and $\mathrm{W}_{\mathrm{P}}$ and $\mathrm{W}_{\mathrm{T}}$ to the direct flows of wastewater, sludge and ash resulting from the producing and treatment sectors, respectively. The $n \times 1$ vector $x_{P}$ refers to the activity levels of economic sectors, and the $k \times 1$ vector, $x_{T}$, the activity level of wastewater treatment sectors.

Table S1 includes three wastewater treatment processes, namely, oxidation ditch $(\mathrm{OD})$, anaerobic/anoxic/oxic(A2/O) processes, and biological aerated filter $(\mathrm{BF})$, two dewatering processes, i.e., mechanical dewatering with centrifugal dewatering equipment (hereafter termed Dew 80 ) that reduces water content from $96 \%$ to around $80 \%$, and plateframe pressure filtration (hereafter termed Dew 60) that combines mechanical dewatering with chemical methods and reduces the water content to below $60 \%$, and three types of sludges, which are raw sludge (Sludge 90) from the wastewater treatment process with water content above $90 \%$, Sludge 80 with water content less than $80 \%$ obtained by subjecting Sludge 90 to Dew 80, and Sludge 60 with water content less than $60 \%$ obtain ed by subjecting Sludge 90 to Dew 60 . The treatment options for dewatered wet sludge include landfill, incineration, and composting. 
Table S1 Framework of the $\mathrm{W}^{2} \mathrm{IO}$ table

\begin{tabular}{|c|c|c|c|c|c|c|c|c|c|c|c|c|c|c|}
\hline \multirow{3}{*}{$\begin{array}{l}\text { Economic } \\
\text { sectors }\end{array}$} & \multicolumn{2}{|c|}{ Economic sectors } & \multicolumn{7}{|c|}{ Wastewater treatment sectors (k) } & \multicolumn{4}{|c|}{ Final demand (f) } & \multirow{3}{*}{$\begin{array}{l}\mathrm{O} \\
\mathrm{ut} \\
\mathrm{pu} \\
\mathrm{t}\end{array}$} \\
\hline & \multirow{2}{*}{$\begin{array}{l}\begin{array}{l}\text { Production } \\
\text { sectors(n) }\end{array} \\
1,2 \ldots 139\end{array}$} & \multirow[t]{2}{*}{$\begin{array}{l}\text { Com } \\
\text { post }\end{array}$} & \multicolumn{3}{|c|}{$\begin{array}{l}\text { Wastewater } \\
\text { treatment }\end{array}$} & \multicolumn{4}{|c|}{ Sludge treatment } & \multirow{2}{*}{$\begin{array}{l}\text { Cons } \\
\text { umpti } \\
\text { on }\end{array}$} & \multirow{2}{*}{$\begin{array}{l}\text { Capit } \\
\text { al } \\
\text { form } \\
\text { ation }\end{array}$} & \multirow{2}{*}{$\begin{array}{l}\text { Gove } \\
\text { rnme } \\
\text { nt } \\
\text { expe } \\
\text { nditu } \\
\text { re }\end{array}$} & \multirow{2}{*}{$\begin{array}{l}\text { Ex } \\
\text { po } \\
\text { rt }\end{array}$} & \\
\hline & & & $\mathrm{A} 2 \mathrm{O}$ & OD & BAF & $\begin{array}{l}\text { Dew } \\
1\end{array}$ & $\begin{array}{l}\text { Dew } \\
2\end{array}$ & $\begin{array}{l}\text { Land } \\
\text { fill }\end{array}$ & $\begin{array}{l}\text { Incin } \\
\text { erati } \\
\text { on }\end{array}$ & & & & & \\
\hline $\begin{array}{l}1 \\
2 \\
\ldots \\
139 \\
\text { Compost }\end{array}$ & \multicolumn{2}{|l|}{$X_{P}$} & \multicolumn{7}{|c|}{$X_{T}$} & \multicolumn{4}{|c|}{$Y_{P}$} & $x_{P}$ \\
\hline \multicolumn{15}{|c|}{ Waste/wastewater (m) } \\
\hline Wastewater (t) & \multirow{5}{*}{\multicolumn{2}{|c|}{$W_{P}$}} & \multirow{5}{*}{\multicolumn{7}{|c|}{$W_{T}$}} & \multirow{5}{*}{\multicolumn{4}{|c|}{$Y_{W}$}} & \multirow[t]{5}{*}{$x_{W}$} \\
\hline Sludge $90(\mathrm{t})$ & & & & & & & & & & & & & & \\
\hline Sludge $80(\mathrm{t})$ & & & & & & & & & & & & & & \\
\hline Sludge $60(\mathrm{t})$ & & & & & & & & & & & & & & \\
\hline Ash (t) & & & & & & & & & & & & & & \\
\hline
\end{tabular}

The balancing equations of products and waste are given by:

$$
\begin{gathered}
\sum_{j=1}^{n}\left(X_{P}\right)_{i j}+\sum_{j=1}^{k}\left(X_{T}\right)_{i j}+\sum_{j=1}^{k}\left(Y_{P}\right)_{i j}=\left(x_{P}\right)_{i} \\
\sum_{j=1}^{n}\left(W_{P}\right)_{i j}+\sum_{j=1}^{k}\left(W_{T}\right)_{i j}+\sum_{j=1}^{k}\left(Y_{W}\right)_{i j}=\left(x_{W}\right)_{i}
\end{gathered}
$$

The matrix of input coefficients, $A$ 's, and wastewater generation coefficients, G's, are given by:

$$
A_{P}=X_{P}{\widehat{x_{P}}}^{-1}, A_{T}=X_{T}{\widehat{x_{T}}}^{-1}, G_{P}=W_{P}{\widehat{W_{P}}}^{-1} \text {, and } G_{T}=W_{T}{\widehat{W_{T}}}^{-1} \text {, }
$$

where ${ }^{-}$refers to the diagonalized matrix of the variable it attaches. Using these matrices, (S1) and (S2) can be rewritten as:

$$
\begin{aligned}
& \sum_{j=1}^{n}\left(A_{P}\right)_{i j}\left(x_{P}\right)_{j}+\sum_{j=1}^{k}\left(A_{T}\right)_{i j}\left(x_{T}\right)_{j}+\sum_{j=1}^{k}\left(Y_{P}\right)_{i j}=\left(x_{P}\right)_{i} \\
& \sum_{j=1}^{n}\left(G_{P}\right)_{i j}\left(x_{P}\right)_{j}+\sum_{j=1}^{k}\left(G_{T}\right)_{i j}\left(x_{T}\right)_{j}+\sum_{j=1}^{k}\left(Y_{W}\right)_{i j}=\left(x_{W}\right)_{i}
\end{aligned}
$$


or using matrix notations as:

$$
\left(\begin{array}{ll}
A_{P} & A_{T} \\
G_{P} & G_{T}
\end{array}\right)\left(\begin{array}{l}
x_{P} \\
x_{T}
\end{array}\right)+\left(\begin{array}{c}
y_{P} \\
y_{W}
\end{array}\right)=\left(\begin{array}{c}
x_{P} \\
x_{W}
\end{array}\right)
$$

This system is not solvable, because of the asymmetry; wastewater occurs on the right-hand side, while the levels of wastewater treatment occur on the left-hand side ${ }^{7-8}$. While the original form of (S5) is not solvable because of this reason, it can be transformed into a solvable symmetric one by establishing the allocation of different types of wastewater to different wastewater treatment processes ${ }^{7}$ This allocation is represented by the allocation matrix $S$ of order $k \times m$, where its $i-j$ element $S_{i j}$ refers to the share of waste $j$ that is allocated to the treatment process $i$.

By use of S, (S5) is transformed to a symmetric system in terms of goods production and wastewater treatment:

$$
\left(\begin{array}{cc}
A_{P} & A_{T} \\
S G_{P} & S G_{T}
\end{array}\right)\left(\begin{array}{l}
x_{P} \\
x_{T}
\end{array}\right)+\left(\begin{array}{c}
y_{p} \\
S y_{w}
\end{array}\right)=\left(\begin{array}{c}
x_{P} \\
S x_{W}
\end{array}\right)=\left(\begin{array}{c}
x_{P} \\
x_{T}
\end{array}\right)
$$

where $x_{T}=S x_{W}$ refers to the output of waste treatment sectors, i.e., the amount of waste treated, with the solution:

$$
\left(\begin{array}{c}
x_{P} \\
x_{T}
\end{array}\right)=\left(\begin{array}{cc}
I-A_{P} & -A_{T} \\
-S G_{P} & I-S G_{T}
\end{array}\right)^{-1}\left(\begin{array}{c}
y_{P} \\
S y_{w}
\end{array}\right)
$$

Finally, multiplication of G's from the left gives the $m \times n$ matrix referring to $\mathrm{W}^{2} \mathrm{~F}$ of products, $W^{2} F_{P}$, and $m \times t$ matrix referring to $\mathrm{W}^{2} \mathrm{~F}$ of direct discharge from final demand sectors, $W^{2} F_{w}$ :

$$
\left(\begin{array}{ll}
W^{2} F_{P} & W^{2} F_{w}
\end{array}\right)=\left(\begin{array}{ll}
G_{P} & G_{T}
\end{array}\right)\left(\begin{array}{cc}
I-A_{P} & -A_{T} \\
-S G_{P} & I-S G_{T}
\end{array}\right)^{-1}\left(\begin{array}{cc}
\widehat{y_{P}} & 0 \\
0 & \widehat{S y_{w}}
\end{array}\right)
$$

\subsubsection{Adjusting for imports}

The flows of goods and waste in the Xiamen IO table include imports from other provinces and abroad. A straight application of the above footprint calculation without considering this fact could result in overestimating the footprints on Xiamen because the imports are not produced in Xiamen. To deal with this issue, we adjusted the flows for 
imports along the Chenery-Moses model ${ }^{9}$. Denoting by $y_{\text {Import }}$ the vector of imports, we define the share of import of a product in its total supply, $m_{i}$, as:

$$
m_{i}=y_{\text {Import }} /\left(x_{P}+y_{\text {Import }}\right)
$$

With the import share thus defined, $y_{P}$, in (S7) is adjusted for imports by:

$$
y_{P d}=(\widehat{1-m}) \sum y_{P}
$$

resulting in equation (3) in the text. The corresponding adjustment for the flow of waste/wastewater was not necessary because of the absence of imports. With $m_{i}$ and $y_{P d}$ thus obtained, (2) is adjusted for imports as:

$$
\left(\begin{array}{ll}
W^{2} F_{P} & W^{2} F_{w}
\end{array}\right)=\left(\begin{array}{ll}
G_{P}^{*} & G_{T}^{*}
\end{array}\right)\left[(I-(I-\widehat{m}))\left(\begin{array}{cc}
A_{P} & A_{T}^{*} \\
S G_{P}^{*} & S G_{T}^{*}
\end{array}\right]^{-1}\left(\begin{array}{cc}
\widehat{y_{P}} & 0 \\
0 & \widehat{S y_{W}}
\end{array}\right)\right.
$$

\subsection{The $\mathrm{W}^{2} \mathrm{IO}$ table and other data}

\subsubsection{Production sector classification}

The IO table in Xiamen contains 139 sectors (Table S2), with a water supply and production aggregated with wastewater treatment.

Table S2 Production sector classification: Xiamen IO table

\begin{tabular}{llll}
\hline & Sector & 37 & Printing and record medium reproduction \\
\hline 1 & Crop cultivation & 38 & Cultural, sporting and recreational products \\
2 & Forestry & 39 & Petroleum refining and nuclear fuel \\
3 & Livestock and products & 40 & Coking \\
4 & Fishery & 41 & Raw chemical materials \\
5 & Technical services for agriculture & 42 & Chemical fertilizers \\
6 & Coal mining and processing & 43 & Chemical pesticides \\
7 & Crude petroleum and natural gas & 44 & Chemicals for painting, dying and others \\
8 & Ferrous metal ore mining & 45 & Synthetic chemicals \\
9 & Non-ferrous metal ore mining & &
\end{tabular}


10 Non-metallic minerals and other mining

Mining auxiliary services and other mining

11

products

2 Grain mill products

13 Feeding stuff production

14 Vegetable oil and forage

15 Sugar refining

16 Slaughtering and meat processing

17 Prepared fish and seafood

18 Vegetable, fruit and nut processing

19 Convenient foods

20 Liquid milk and dairy products

21 Spices and fermentation products

22 Other food manufacturing

23 Wines, spirits and liquors

24 Non-alcoholic beverage

25 Tobacco products

26 Cotton textiles

27 Woolen textiles

28 Hemp textiles

29 Finished textile products

30 Knitted mills

31 Wearing apparel

32 Leather, furs, down and related products

33 Shoes

Sawmills, fiberboard, and products of wood,

34 bamboo, cane, palm, straw, etc.

35 Furniture

36 Paper and paper products
Chemicals for special usages

Surfactant Detergent \& Cosmetics

Medical and pharmaceutical products

Chemical fibers

Rubber products

Plastic products

Cement, lime and gypsum

Cement products and other similar products

Brick, tile, stone and other building materials

Glass and glass products

Ceramic products

Fireproof products

Other non-metallic mineral products

Iron smelting

Steel smelting

Iron alloy smelting

Nonferrous metal smelting

Nonferrous metal processing

Metal products

Boiler, engines and turbine

Metalworking machinery

Lifting transport equipment

Pump, valve, compressor and similar

machinery

Culture, office machinery

Mining, metallurgy and construction

equipment

Chemical engineering, wood and non-

2 metallic processing equipment

Cultivation, forestry, animal husbandry and fishery machinery

\begin{tabular}{llll}
\hline \multicolumn{2}{l}{ Sector } & \multicolumn{2}{c}{ Sector } \\
\hline 74 & Other special equipment & 108 & Tube transportation \\
75 & Motor vehicles & 109 & Service agent \\
76 & Components for vehicles & 110 & Warehousing \\
77 & Railroad transport equipment & 111 & Post \\
78 & Ship building & 112 & Hotel \\
79 & Other transport machinery & 113 & Eating and drinking places \\
80 & Generators & 114 & Telecommunication \\
\hline
\end{tabular}




\begin{tabular}{|c|c|c|c|}
\hline 81 & $\begin{array}{l}\text { Power transmission, distribution and control } \\
\text { equipment }\end{array}$ & 115 & Software \\
\hline 82 & Cable and electrical materials & 116 & Finance \\
\hline 83 & Battery & 117 & Financial market \\
\hline 84 & Household appliances & 118 & Insurance \\
\hline 85 & Other electric machinery and equipment & 119 & Real estate \\
\hline 86 & Electronic computer & 120 & Leasehold \\
\hline 87 & Communication equipment & 121 & Business services \\
\hline 88 & Radar and broadcasting equipment & 122 & Scientific research and experiment \\
\hline 89 & Household audio-visual equipment & 123 & Special technical services \\
\hline 90 & Electronic elements and devices & 124 & $\begin{array}{l}\text { Science \& technology exchange and } \\
\text { promotion services }\end{array}$ \\
\hline 91 & Other electronic equipment & 125 & Water conservancy \\
\hline 92 & Instruments and measuring equipment & 126 & Environmental management \\
\hline 93 & Other manufactured products & 127 & Public infrastructure management \\
\hline 94 & Scrap and waste recycling & 128 & Residential services \\
\hline 95 & Repair of metal products and machinery & 129 & Other social services \\
\hline 96 & Electricity and heat production and supply & 130 & Education services \\
\hline 97 & Gas production and supply & 131 & Health services \\
\hline 98 & Water production and supply & 132 & Social welfare \\
\hline 99 & Construction & 133 & News press \\
\hline 100 & Civil engineering & 134 & Radio, television, film and audio-video \\
\hline 101 & Installation & 135 & Culture and arts \\
\hline 102 & Decoration & 136 & Sports \\
\hline 103 & Wholesale and retail trade & 137 & Recreational services \\
\hline 104 & Railway transportation & 138 & Social security \\
\hline 105 & Road transportation & 139 & $\begin{array}{l}\text { Public administration and social } \\
\text { organization }\end{array}$ \\
\hline 106 & Water transportation & & \\
\hline 107 & Air transportation & & \\
\hline
\end{tabular}

\subsubsection{Correction of the original IO data with RAS}

In the original IO table of Xiamen, "Road transport" ranks as the second-largest intermediate user (365.57 million RMB) of "Crop cultivation" after "Vegetable oil and forage" (624.79 million RMB). However, the corresponding entry in the National IO tables for China was 0 for both the 2012 and 2017 tables. Furthermore, we were not able to find any local data supporting the presence of this large transaction. Accordingly, 
footprint calculation based on the original IO table produced results that are difficult to interpret. We, therefore, decided to replace the entry of this cell with zero. To maintain consistency in the accounting of the resulting IO table, the matrix of input coefficients was subjected to adjustments by the RAS method ${ }^{9}$.

\subsubsection{Data used to develop the $\mathrm{W}^{2} \mathrm{IO}$ table for Xiamen}

The data in Panel A of "Treatment", excluding sludge landfill and incineration, were obtained from XEPB $(2012)^{10}$. For sludge incineration and landfilling, the corresponding data on municipal solid waste was used. The data on sludge composting was obtained from the actual operation data of sludge composting. Using data on investment

expenditure and operating costs of WWTPs ${ }^{10}$, we extracted the data on wastewater treatment separately from the IO table.

The data on wastewater and COD in Panel B of "Production" was obtained from XPSO (2011) ${ }^{11}$. Agriculture is a non-point source of pollution. Agricultural cultivation and fisheries are not included in the domestic sewage pipe network. Only a small amount of large-scale farming wastewater enters the WWTP pipeline. The data on wastewater treatment capacity, sludge generation, and COD were obtained from the annual operation data provided by the Xiamen Municipal Construction Group. Finally, the data on wastewater and COD in Panel B of "Final demand" was obtained from CCNPS (2011) a booklet that gives the factors for wastewater generated by residents in China, divided into five major categories. Xiamen city belongs to the first category of the second district in China and is in the same category as Shanghai, Guangzhou, and Hangzhou. 
Table S3 The allocation matrix $S$ of waste/wastewater to treatment processes

\begin{tabular}{|c|ccccc|}
\cline { 2 - 6 } \multicolumn{1}{c|}{} & \multicolumn{5}{c|}{ Waste/wastewater } \\
\hline & Wastewater & Sludge 90 & $\begin{array}{c}\text { Sludge } \\
80\end{array}$ & $\begin{array}{c}\text { Sludge } \\
60\end{array}$ & Ash \\
\hline A2O & 0.19 & 0.00 & 0.00 & 0.00 & 0.00 \\
OD & 0.43 & 0.00 & 0.00 & 0.00 & 0.00 \\
BF & 0.38 & 0.00 & 0.00 & 0.00 & 0.00 \\
Dewater80 & 0.00 & 0.36 & 0.00 & 0.00 & 0.00 \\
Dewater60 & 0.00 & 0.64 & 0.00 & 0.00 & 0.00 \\
landfill & 0.00 & 0.00 & 0.00 & 0.89 & 1.00 \\
Incineration & 0.00 & 0.00 & 1.00 & 0.11 & 0.00 \\
\hline
\end{tabular}


Table S4 The W'2IO table of Xiamen based on the framework in Table 1.

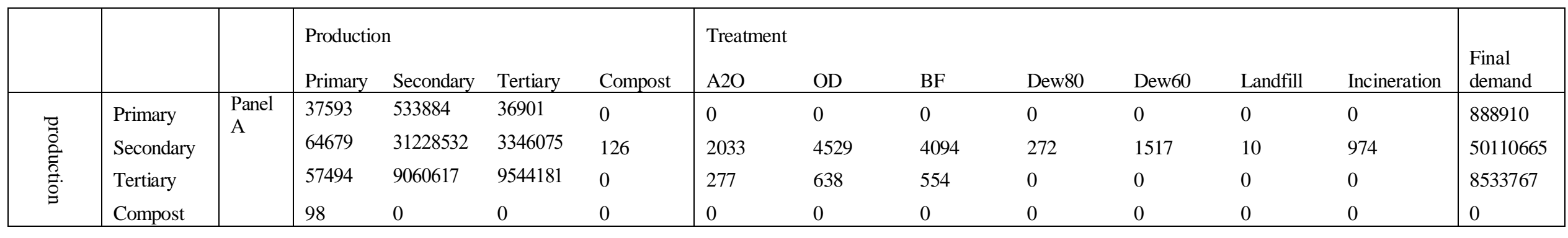

\begin{tabular}{|c|c|c|c|c|c|c|c|c|c|c|c|c|c|c|}
\hline \multirow{5}{*}{ 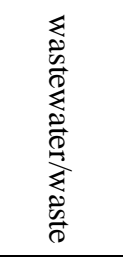 } & wastewater & \multirow{6}{*}{$\begin{array}{l}\text { Panel } \\
\text { B }\end{array}$} & 1 & 3024 & 3153 & 0 & 0 & 0 & 0 & 0 & 0 & 2 & 0 & 14903 \\
\hline & sludge 90 & & 0 & 0 & 0 & 0 & 203604 & 509028 & 343604 & 0 & 0 & 0 & 0 & 0 \\
\hline & sludge 80 & & 0 & 0 & 0 & -30080 & 0 & 0 & 0 & 47054 & 0 & 0 & 0 & 0 \\
\hline & sludge 60 & & 0 & 0 & 0 & 0 & 0 & 0 & 0 & 0 & 75723 & 0 & 0 & 0 \\
\hline & ash & & 0 & 0 & 0 & 0 & 0 & 0 & 0 & 0 & 0 & 0 & 5090 & 0 \\
\hline Effluents & COD & & 4 & 8896 & 7472 & 0 & 1326 & 2309 & 2742 & 0 & 0 & 2 & 0 & 50669 \\
\hline
\end{tabular}

\begin{tabular}{|c|c|c|c|c|c|c|c|c|c|c|c|c|c|c|}
\hline \multirow{7}{*}{ 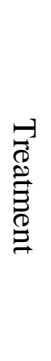 } & $\mathrm{A} 2 \mathrm{O}$ & Part C & 0 & 562 & 585 & 0 & 0 & 0 & 0 & 0 & 0 & 0 & 0 & 2767 \\
\hline & OD & & 0 & 1312 & 1368 & 0 & 0 & 0 & 0 & 0 & 0 & 1 & 0 & 6466 \\
\hline & $\mathrm{BF}$ & & 0 & 1150 & 1199 & 0 & 0 & 0 & 0 & 0 & 0 & 1 & 0 & 5669 \\
\hline & Dew80 & & 0 & 0 & 0 & 0 & 72809 & 182028 & 122873 & 0 & 0 & 0 & 0 & 0 \\
\hline & Dew60 & & 0 & 0 & 0 & 0 & 130795 & 327000 & 220731 & 0 & 0 & 0 & 0 & 0 \\
\hline & landfill & & 0 & 0 & 0 & 0 & 0 & 0 & 0 & 0 & 67242 & 0 & 5090 & 0 \\
\hline & Incineration & & 0 & 0 & 0 & -30080 & 0 & 0 & 0 & 47054 & 8481 & 0 & 0 & 0 \\
\hline
\end{tabular}

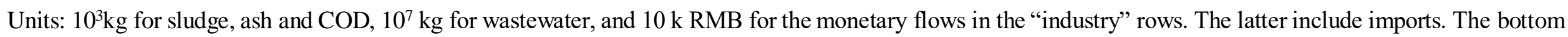
panel (Panel C) gives the flow of waste/wastewater converted to the flow of treatment via allocation matrix in Table S2. 
The upper panel (Panel A) represents the flow of goods and services during production, wastewater/waste treatment sectors, and the final demand in monetary units, whereas the middle panel (Panel B) with the rows referring to waste/wastewater represents the flow of waste/wastewater generated in physical units. Panel $\mathrm{C}$ gives the flow of waste/wastewater converted by the allocation matrix S in Table S2 to the flow among treatment sectors. This converts wastewater discharges into inputs of wastewater treatment services, the generation of raw sludge from wastewater treatment sectors into the generation of dewatering activities, the generation of dewatered sludge into the inputs of incineration and landfill, and the input of sludge into composting as a negative input of incineration because the sludge is incinerated when not recycled as compost.

For instance, of $30 \mathrm{Mt}$ of wastewater discharged from secondary sectors, $11.5 \mathrm{Mt}$ is sent to $\mathrm{BF}, 13 \mathrm{Mt}$ to $\mathrm{OD}$, and the rest to $\mathrm{A} 2 \mathrm{O}$. Of the $203 \mathrm{kt}$ of raw sludge generated by A2O, $13 \mathrm{kt}(64 \%)$ is sent to Dew 60, with the rest being sent to Dew 80. Approximately $89 \%$ of Sludge 60 is landfilled, with the rest being directly incinerated. A sizable amount (64\%) of Sludge 80 is used (recycled) in the composting sector as represented by its negative output in the sector. As Sludge 80 is otherwise incinerated (Table S3), its recycling in the form of composting and subsequent use as a substitute for fertilizers in the agricultural sector leads to a reduction in the amount of incinerated Sludge 80. This is represented in the bottom panel referring to treatment by the occurrence of a negative input of incineration in the composting sector. If not recycled, Sludge 80 would be incinerated (Table S3), leading to the generation of $5 \mathrm{kt}$ of ash, which would then be landfilled.

\subsubsection{COD from different sources of wastewater discharge}

Table S5 COD and wastewater discharge

\begin{tabular}{lrrrr}
\hline & \multicolumn{1}{l}{ Toilet } & \multicolumn{1}{l}{ Kitchen } & Bath-wash & Source \\
\hline COD $(\mathrm{kg} / \mathrm{y})$ EU & 27.5 & 16 & 3.7 & Ref 13 \\
Wastewater $\left(\mathrm{m}^{3} / \mathrm{y}\right)$ EU & 19 & 18 & 18 & Ref 13 \\
Wastewater $\left(\mathrm{m}^{3} / \mathrm{y}\right)$ : Singapore & 24 & 33 & 88 & Ref 14 \\
COD $(\mathrm{kg} / \mathrm{y})$ Xiamen & 12.76 & 17.64 & 5.44 & EU value Ref 13 \\
Wastewater $\left(\mathrm{m}^{3} / \mathrm{y}\right)$ Xiamen & 8.82 & 19.84 & 26.46 & Singapore share \\
& & & & Ref 14 \\
\hline
\end{tabular}


Due to the lack of Chinese data on COD by sources of wastewater discharge, we used the EU data on COD concentration of wastewater from toilets, $27.5 / 19=1.45 \mathrm{~kg} / \mathrm{m}^{3}$, provided by ${ }^{13}$ Henze et al. (2002, Table 1.17). As for the share of wastewater discharge by sources, we used the data on Singapore (16\% for toilet) taken from JWRC (2018) ${ }^{14}$ instead of the EU value. This choice was made considering the similarity between Xiamen and Singapore in terms of the climatic zone and diet patterns. This resulted in the estimated share for Xiamen of toilet wastewater in total COD of 0.36 .

\subsubsection{Diet pattern, toilet discharge, and carbon content of food}

Table S6 Data on food (diet, toilet discharge, and carbon content)

\begin{tabular}{lcccc}
\hline & Food consumption & Toilet discharge & Carbon content & Spanish diet \\
\hline Units & $\mathrm{kg} / \mathrm{p} / \mathrm{y}$ & $1 / \mathrm{kg}$ & $100 \mathrm{~g}-\mathrm{C} / \mathrm{g}$-food & $\mathrm{kg} / \mathrm{p} / \mathrm{y}$ \\
$\begin{array}{l}\text { Source } \\
\text { Ref } 15\end{array}$ & Ref 16 & Ref 17 & Ref 16 \\
$\begin{array}{l}\text { Grain mill } \\
\text { products }\end{array}$ & 41.9 & 20.5 & 32.7 & 41.9 \\
$\begin{array}{l}\text { Vegetable oil and } \\
\text { forage }\end{array}$ & 8.9 & 20 & 76.7 & 22 \\
$\begin{array}{l}\text { Slaughtering and } \\
\text { meat processing }\end{array}$ & 43.4 & 25 & 25.5 & 66 \\
$\begin{array}{l}\text { Prepared fish and } \\
\text { seafood }\end{array}$ & 18.1 & 25.5 & 14.3 & 37 \\
$\begin{array}{l}\text { Vegetable, fruit, } \\
\text { and nut processing }\end{array}$ & 160.5 & 24 & 5.0 & 225 \\
$\begin{array}{l}\text { Liquid milk and } \\
\text { dairy products }\end{array}$ & 12.8 & 25 & 6.3 & 143 \\
$\begin{array}{l}\text { Other food } \\
\text { manufacturing }\end{array}$ & 6.4 & 19.5 & 32.7 & 6.4 \\
$\begin{array}{l}\text { Wines, spirits and } \\
\text { liquors }\end{array}$ & 6.7 & 24 & 4.1 & 6.7 \\
$\begin{array}{l}\text { Non-alcoholic } \\
\text { beverage }\end{array}$ & 2.7 & 24 & 4.1 & 2.7 \\
\hline
\end{tabular}

\subsection{Scenario analysis}

Two scenarios were considered to assess the effects of possible changes in industrial structure and diet patterns. The first one (Scenario 1) is based on the rate of industrial growth prescribed in the 13th Five-Year Plan for economic and social development in Xiamen city. In that plan, sectors such as electronic information and mechanical manufacturing are expected to play a vital role in economic growth, with the output of 
electronic information expected to increase from 0.3 trillion RMB in 2015 to 0.7 trillion RMB in 2020, or a 2.3-fold increase. To assess the impacts of planned industrial growth, we evaluated the effects on wastewater and sludge of the same 2.3 -fold increase in the final demand for the products of 15 manufacturing sectors consisting of cars, ships, machinery, electronics, computer, and communication equipment. Denoting by $D W_{S 1}$, $W 2 F_{S 1}$, and $W 2 F_{S 1}$ the direct wastewater discharge, wastewater footprint, and sludge footprint under Scenario 1, respectively, we have

$$
\begin{gathered}
D W_{S 1}=\sum_{i} r_{i} \times D W_{i} \\
W 2 F_{S 1}=\sum_{i} r_{i} \times W 2 F_{i} \\
S F_{S 1}=\sum_{i} r_{i} \times S F_{i}
\end{gathered}
$$

where $r_{i}$ refers to the expected rate of change in the output of sector $i$.

The second scenario (Scenario 2) refers to a possible shift in diet from the traditional Chinese one mostly based on staples toward a European (Spanish) one involving larger amounts of animal-sourced foods. The evaluation was carried out by altering the consumption of "Vegetable oil and forage" "Slaughtering and meat processing", "Prepared fish and seafood", "Vegetable, fruit and nut processing," and "Liquid milk and dairy products" to the Spanish level (the last column of Table S3), and applying the same calculation as in Scenario 1.

\subsection{Sensitivity analysis}

To examine the robustness of the results, we conducted a sensitivity analysis for key parameters based on the sensitivity elasticity of parameters ${ }^{18-19}$, which indicates the ratio by which a change in "key parameters" changes the results, $\mathrm{W}^{2} \mathrm{~F}$ and SF in our case. The elasticity is given by

$$
\mathrm{EL}=\frac{\partial y}{\partial a} \times \frac{a}{y}
$$

where $\boldsymbol{y}$ denotes $\mathrm{W}^{2} \mathrm{~F}$ or SF and $\boldsymbol{a}$ the parameter under study. Among others, $\boldsymbol{\theta}_{\boldsymbol{i}}$ and $\boldsymbol{\alpha}_{\boldsymbol{j}}$ are considered as key parameters. 


\section{Results}

\subsection{Direct discharge versus footprint}

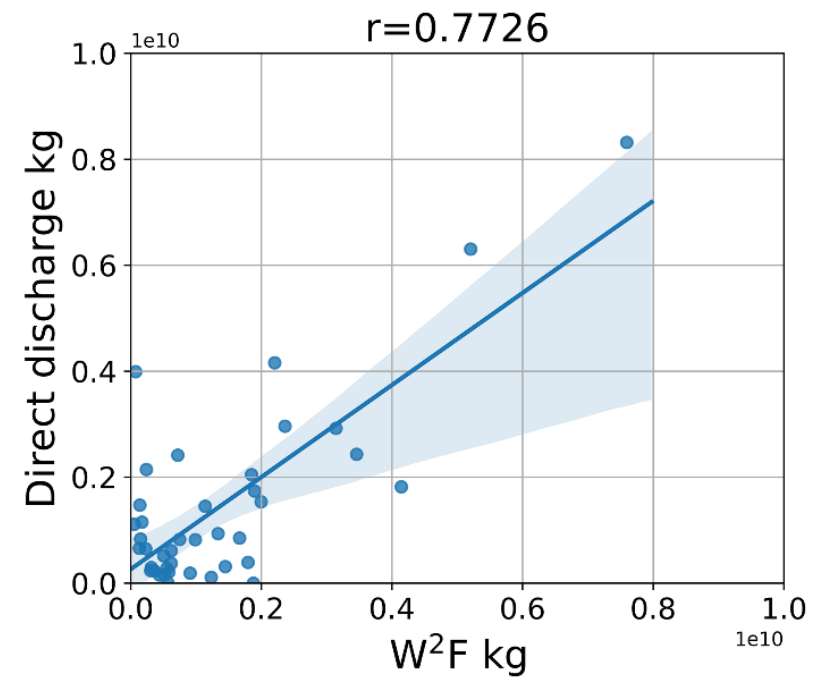

Figure $S 1$ Direct discharge versus $W^{2} F$ of the largest 40 sector

\subsection{Wastewater and sludge footprint by final demand categories}

In terms of final demand categories, the largest share of $\mathrm{W}^{2} \mathrm{~F}(42 \%)$ is attributed to export, followed by urban household consumption (33\%). The largest share of SF (78\%) is attributed to urban household consumption, followed by export (10\%) (Figure S2).
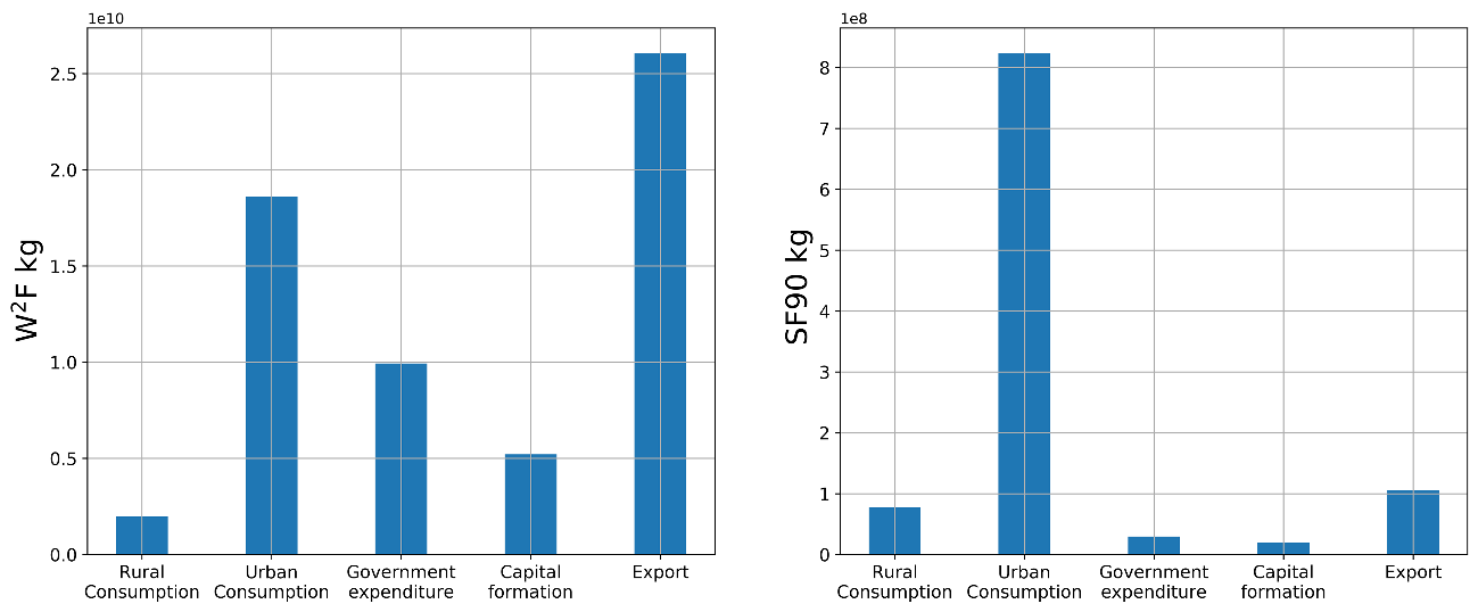

Figure S2 Wastewater and sludge footprint by final demand categories 


\subsection{Sensitivity analysis}

\subsubsection{The sensitivity of pre-consumption $W^{2} F$ and $S F$ to input and waste generation coefficients}

Table S7 shows input and wastewater generation coefficients elasticities of preconsumption $\mathrm{W}^{2} \mathrm{~F}$ and $\mathrm{SF}$, and gives the ratio by which a change in relevant coefficients changes $\mathrm{W}^{2} \mathrm{~F}$ or SF. For instance, the value 0.000003 at the upper-left cell shows that a one $\%$ change in the input coefficient of electricity of the composting process changes the wastewater footprint by 0.000003 , that is, practically no impact. The results indicate that for most cases the elasticities are small, with the occurrence of large elasticities concentrated to sludge generation coefficients. The largest one, 2.77, refers to the effects on sludge80 footprint of the sludge90 generation coefficients of Dew80, Dew60, landfill, and incineration treatment processes. It implies that a one $\%$ change in the coefficient change would induce a $2.77 \%$ change in SF of sludge 80 . Since these coefficients were directly obtained from data on the real operation of WWTPs in the city, they are of high reliability, implying the robustness of our results of SF.

Table S7 Sensitivity elasticity of pre-consumption $W^{2} F$ and SF to input and waste generation coefficients

\begin{tabular}{cc|rccc}
\hline & Footprint & & & & \\
Coefficients & & Wastewater & Sludge90 & Sludge 80 & Sludge60 \\
\hline & Compost & 0.000003 & 0.000000 & 0.000002 & 0.000001 \\
& A2O & 0.000037 & 0.000000 & 0.000029 & 0.000011 \\
Electricity & OD & 0.000082 & 0.000000 & 0.000066 & 0.000024 \\
& BF & 0.000068 & 0.000000 & 0.000055 & 0.000020 \\
& Dew80 & 0.000002 & 0.000000 & 0.000002 & 0.000001 \\
& Dew60 & 0.000004 & 0.000000 & 0.000003 & 0.000001 \\
& Landfill & 0.000000 & 0.000000 & 0.000000 & 0.000000 \\
& Incineration & 0.000002 & 0.000000 & 0.000001 & 0.000001 \\
\hline & Compost & 0.000000 & 0.000000 & 0.000000 & 0.000000 \\
& A2O & 0.000000 & 0.000000 & 0.000000 & 0.000000 \\
& OD & 0.000000 & 0.000000 & 0.000000 & 0.000000 \\
Wastewater & BF & 0.000000 & 0.000000 & 0.000000 & 0.000000
\end{tabular}




\begin{tabular}{|c|c|c|c|c|c|}
\hline & Dew80 & 0.000000 & 0.000000 & 0.000000 & 0.000000 \\
\hline & Dew60 & 0.000000 & 0.000000 & 0.000000 & 0.000000 \\
\hline & Landfill & 0.000280 & 0.000000 & 0.000000 & 0.000000 \\
\hline & Incineration & 0.000280 & 0.000000 & 0.000227 & 0.000082 \\
\hline \multirow{8}{*}{ Sludge90 } & Compost & 0.000000 & 0.000000 & 0.000000 & 0.000000 \\
\hline & $\mathrm{A} 2 \mathrm{O}$ & 0.000000 & 0.192764 & 0.000000 & 0.000000 \\
\hline & OD & 0.000062 & 0.481927 & 0.534416 & 0.192783 \\
\hline & $\mathrm{BF}$ & 0.000216 & 0.325310 & 1.870517 & 0.674760 \\
\hline & Dew80 & 0.000321 & 0.000000 & 2.772421 & 1.000108 \\
\hline & Dew60 & 0.000321 & 0.000000 & 2.772421 & 1.000108 \\
\hline & Landfill & 0.000321 & 0.000000 & 2.772421 & 1.000108 \\
\hline & Incineration & 0.000321 & 0.000000 & 2.772421 & 1.000108 \\
\hline \multirow{8}{*}{ Sludge 80} & Compost & 0.000000 & 0.000000 & -1.772122 & 0.000000 \\
\hline & $\mathrm{A} 2 \mathrm{O}$ & -0.000026 & 0.000000 & -1.772143 & -0.000007 \\
\hline & OD & -0.000026 & 0.000000 & -1.772143 & -0.000007 \\
\hline & $\mathrm{BF}$ & -0.000026 & 0.000000 & -1.772143 & -0.000007 \\
\hline & Dew80 & -0.000026 & 0.000000 & 0.999976 & -0.000007 \\
\hline & Dew60 & 0.000015 & 0.000000 & 1.000013 & 0.000004 \\
\hline & Landfill & 0.000015 & 0.000000 & 1.000013 & 0.000004 \\
\hline & Incineration & 0.000015 & 0.000000 & 1.000013 & 0.000004 \\
\hline \multirow{8}{*}{ Sludge 60} & Compost & 0.000000 & 0.000000 & 0.000000 & 0.000000 \\
\hline & $\mathrm{A} 2 \mathrm{O}$ & 0.000000 & 0.000000 & 0.000000 & 0.000000 \\
\hline & OD & 0.000000 & 0.000000 & 0.000000 & 0.000000 \\
\hline & $\mathrm{BF}$ & 0.000000 & 0.000000 & 0.000000 & 0.000000 \\
\hline & Dew80 & 0.000000 & 0.000000 & 0.000000 & 0.000000 \\
\hline & Dew60 & 0.000000 & 0.000000 & 0.000000 & 1.000000 \\
\hline & Landfill & 0.000267 & 0.000000 & 0.000217 & 1.000090 \\
\hline & Incineration & 0.000267 & 0.000000 & 0.000217 & 1.000090 \\
\hline
\end{tabular}

Note: The first and second columns show the names of input and waste generation coefficient. The first row show the names of wastewater and sludge footprints.

\subsubsection{The sensitivity of post-consumption $\mathrm{W}^{2} \mathrm{~F}$ and $\mathrm{SF}$ to key parameters}

Table S8 shows the sensitivity elasticities of post-consumption $\mathrm{W}^{2} \mathrm{~F}$ and SF to key parameters, $\theta_{i}$ and $\alpha_{j}$. The first block shows the effects of a change in the discharge rate of toilet water associated with the excretion of food item $i$, that is, $\theta_{i}$, on post- 
consumption WWF. For instance, the value 0.12 of the upper-left cell indicates that a one percent change in the amount of discharge of toilet water associated with the excretion of grain mill products results in a $0.12 \%$ change in the amount of post-consumption $\mathrm{W}^{2} \mathrm{~F}$. The results indicate that the elasticities are rather small, with none exceeding 0.6. The largest value is observed for "Vegetable, fruits, and nut processing" on post SF, because of its largest share (53\%) in the total mass food consumption.

The second block of Table S7 shows the impacts of a change in the ratio of raw sludge to total COD, $\alpha_{j}$, of the three WWTPs on the amount of post-consumption $\mathrm{W}^{2} \mathrm{~F}$. The results indicate that the amount of post-consumption $\mathrm{W}^{2} \mathrm{~F}$ is relatively sensitive to the parameter of OD treatment, which can be explained by that its treatment capacity is larger than the other two treatment processes. The parameter is obtained from annual WWTPs operation data in the city and hence is of high credibility, implying the robustness of our post-consumption SF results.

Table S8 Sensitivity elasticity of post-consumption $\mathrm{W}^{2} \mathrm{~F}$ and SF with respect to key parameters

\begin{tabular}{|c|c|c|c|}
\hline & $\begin{array}{l}\text { Footprint } \\
\text { Parameters }\end{array}$ & Wastewater & Sludge 90 \\
\hline \multirow{9}{*}{$\theta_{i}$} & Grain mill products & 0.12 & \\
\hline & Vegetable oil and forage & 0.03 & \\
\hline & $\begin{array}{l}\text { Slaughtering and meat } \\
\text { processing }\end{array}$ & 0.15 & \\
\hline & Prepared fish and seafood & 0.06 & \\
\hline & $\begin{array}{l}\text { Vegetable, fruit and nut } \\
\text { processing }\end{array}$ & 0.54 & \\
\hline & $\begin{array}{l}\text { Liquid milk and dairy } \\
\text { products }\end{array}$ & 0.05 & \\
\hline & Other food manufacturing & 0.02 & \\
\hline & Wines, spirits and liquors & 0.02 & \\
\hline & Non-alcoholic beverage & 0.01 & \\
\hline \multirow{3}{*}{$\alpha_{j}$} & $\mathrm{~A} 2 \mathrm{O}$ & & 0.19 \\
\hline & OD & & 0.48 \\
\hline & $\mathrm{BF}$ & & 0.33 \\
\hline
\end{tabular}

Note: The first and second columns show the parameters. The first row show the names of wastewater technology and sludge footprints. 


\subsection{Transboundary impacts}

In the literature on carbon footprint based on multi-regional input-output (MRIO) analysis it is common to look at the impacts embodied in trade. While the current IO data is a single region one, it is possible to estimate the amounts of wastewater and sludge embodied in trade, assuming that the technology of the exporting countries is the same as that of Xiamen, that is, $\widehat{m}=0$ in (S10). The results in Table S9 indicate that Xiamen is a net exporter of wastewater and sludge, although the extent of "trade surplus" for the latter is much smaller. It is not the case that the city is keeping its own water resources clean at the expense of other regions of China.

Table S9 Wastewater and sludge embodied in trade

\begin{tabular}{lcc}
\hline & Embodied in export & Embodied in import \\
\hline Wastewater $\left(10^{7} \mathrm{~kg}\right)$ & 6778 & 5813 \\
Sludge90 $\left(10^{3} \mathrm{~kg}\right)$ & 291741 & 274283 \\
\hline
\end{tabular}

\section{References}

(1) Zhang, Q.H.; Yang, W.N.; Ngo, W.N.; Guo, W.S.; Jin, P.K.; Dzakpausu, M.; Yang, S.J.; Wang, Q.; Wang. X.C; Ao, D. Current status of urban wastewater treatment plants in China. Environ Int. 2016, 92-93: 11-22.

(2) MOHURD (Ministry of Housing and Urban-Rural Development of People's Republic of China), 2007. The disposal of Sludge from Municipal Wastewater Treatment Plant-Sludge Quality for Colandfilling (CJ/T 249-2007). (In Chinese)

(3) Yang, G.; Zhang, G.; Wang, H. Current state of sludge production, management, treatment and disposal in China. Water Research. 2015, 78: 60-73.

(4) MEE(Ministry of Ecology and Environment of People's Republic of China). Guideline on Best Available Technologies of Pollution Prevention and Control for Treatment and Disposal of Sludge from Municipal Wastewater Treatment Plant. 2010. (In Chinese).

(5) GSC (General Office of the State Council). Pilot Work Plan for the Construction of Zero-waste Cities. 2018. In Chinese.

(6) Nakamura, S.; Kondo, Y. Waste Input-Output Analysis: Concepts and Application to Industrial Ecology. Springer. 2009.

(7) Nakamura, S.; Kondo, Y. Input-Output Analysis of Waste Management. J Ind Ecol. 2002, 6(1): 39-63.

(8) Nakamura, S.; Nansai, K. "Input-output and hybrid LCA," in Special types of life cycle 
assessment, Ed.M. Finkbeiner Springer, 2016.

(9) Miller, R.E.; Blair, P.D. Input-output analysis: Foundations and Extensions. UK, Cambridge University Press.2009

(10) XEPB (Xiamen Environmental Protection Bureau). Xiamen Annual Environmental statistics report. 2012.(In Chinese)

(11)XPSO(Xiamen Pollution Survey Office). Technical report of the pollution Survey in Xiamen City, Fujian Province. 2011. (In Chinese)

(12)CCNPS (Compilation Committee for National Pollution Survey). Household Discharge Coefficient and Use Instructions. China Environmental Science Press. 2011.(in Chinese)

(13)Henze, M.; Harremoës, P.; Jansen, J.; Arvin, E. Wastewater treatment. Biological and che mical processes. 3rd ed. Berlin, Springer, 2002.

(14)JWRC. Japan Water Research Center. http://www.jwrc-net.or.jp/map/shiyouryou_map.html. (In Japanese).

(15)XSB (Xiamen Statistic Bureau). Yearbook of Xiamen Special Economic Zone. 2013. http://202.109.255.156:8130/files_pub/publish/2013/2013/main0.htm. (In Chinese)

(16) Munoz, I.; Canals, L.; Clift, R. Consider a Spherical Man. J Ind Ecol. 2008, 12: 521-537.

(17) Yan, Z.; Cui, S.; Li, G.; Ren, Y. Dynamics and Environmental Load of Food Carbon Consumption During Urbanization: A Case Study of Xiamen City,China. Environmental Science. 2013, 34(4): 1636-1644. (In Chinese)

(18)Heijungs, R.; Lenzen, M. Error propagation methods for LCA - a comparison. Int J Life Cycle Ass . 2014, 19(7): 1445-1461.

(19)Lin, C.; Qi, J.; Liang, S.; Feng, C.; Wiedmann, T.; Liao, Y.; Yang, X.; Li, Y.; Mi, Z.; Yang, Z. Saving less in China facilitates global CO2 mitigation. Nat. Commun. 2020, 11: 1-12. 